Jurnal The Messenger, Vol. 10, No. 1, January 2018, pp. 93-103

P-ISSN: 2086-1559, E-ISSN: 2527-2810

DOI: $10.26623 /$ themessenger.v10i1.417

\title{
The Influence of Brand Image Quality to Students' Expectation and Satisfaction of Lecture at Politeknik Indonusa Surakarta
}

\section{Pengaruh Kualitas Citra Merek terhadap Ekspektasi dan Kepuasan Mahasiswa Kuliah di Politeknik Indonusa Surakarta}

\author{
A. Anditha Sari ${ }^{1}$ \\ ${ }^{1}$ Study Program of Mass Communication, Politeknik Indonusa Surakarta, Jl. KH \\ Samanhudi, No. 31, Laweyan Surakarta, Indonesia \\ *e-mail: anditha@poltekindonusa.ac.id
}

\begin{abstract}
An educational institution should be able to prove the quality of education. Consumers, in this case are students, need the proof of achievement, assessment, certification of quality, and the success of the alumni in getting work related to the field of knowledge. Evaluation is also needed to gain recognition from the community, as well as changes in curriculum and teaching methods that impact to better quality of the graduates. This study aims to analyze brand image influence to the expectations and satisfaction of students by taking sample 100 students from 5 study program i.e D3 Mass Communication, Hospitality, Informatics Management, Automotive, and Pharmacy by using systematic sample technique. Sample criteria that are students who have studied in semester 3 because students with the criteria should be able to evaluate their campus. The result of study indicates that brand image has significant effects to the expectation and satisfaction of the students.
\end{abstract}

Keywords: Brand Image, Expectations, Satisfaction.

\begin{abstract}
Abstrak
Sebuah lembaga pendidikan harus bisa membuktikan kualitas pendidikannya. Konsumen, yang dalam hal ini mahasiswa, perlu melihat bukti prestasi, penilaian, sertifikasi kualitas, dan keberhasilan alumni dalam mendapatkan pekerjaan yang sesuai dengan bidang ilmunya. Evaluasi juga dibutuhkan untuk memperoleh pengakuan dari masyarakat, serta perubahan kurikulum dan metode pengajaran yang berdampak kualitas lulusan yang lebih baik. Penelitian ini dilakukan untuk menganalisis pengaruh citra merek terhadap ekspektasi dan kepuasan mahasiswa. Penelitian ini dilakukan pada mahasiswa dengan mengambil sampel sebanyak 100 mahasiswa dari 5 prodi yaitu D3 Komunikasi Massa, Perhotelan, Manajemen Informatika, Otomotif, dan Farmasi dengan menggunakan teknik pengambilan sampel yaitu systematic sampling. Kriteria sampel yaitu mahasiswa yang telah kuliah di semester 3 (tiga) karena mahasiswa dengan kriteria tersebut dianggap telah mampu melakukan evaluasi terhadap kampus tempat mereka kuliah. Hasil dari penelitian ini menunjukkan bahwa citra merek berpengaruh secara signifikan terhadap ekspektasi dan kepuasan mahasiswa.
\end{abstract}

Kata Kunci: Citra Merek, Ekspektasi, Kepuasan.

Copyright (C) 2018 Universitas Semarang. All rights reserved.

\section{Introduction}

Life is essentially the true educational process. Education is not only preparation process but also is life itself. The educational process shapes humans individually. The educational process also has shaped people as a community, or even formed as a nation and state. In accordance with Law No. 20 of 2003 on National Education System (UU

Article History: Received January 24, 2017; Revised July 28, 2017; Accepted January 25, 2018; Published January 31, 2018 
No. 20/2003, Sistem Pendidikan Nasional), universities can be in the form of universities, polytechnics, high schools, institutes, and academia. Universities or institutions in the field of education have five dimensions of meaning, namely: the dimensions of science (science and technology), the dimensions of education (higher education), social dimension (community life), corporate dimensions (unit and organization), and ethical dimensions.

For people who choose to continue and complete their education until the highest level, they will face various choices and problems. Choosing to continue education to college, the community will be faced with various college options. In addition, society will also be faced with so many considerations to be considered. The demands on universities today are not only limited to the ability to produce academically measured graduates, but the whole program and the higher education institutions must be able to prove the high quality and supported by the existing accountability so that it can lead to various college choices that become consideration for prospective students. Determining choice is not easy and it takes the right thinking based on various considerations. These activities belong to the pre-purchase stage, because it is still in the search for information about an object. Based on the survey conducted by daily KOMPAS on 25 April 2011, p. 4 in Jakarta, there are several variables that greatly influence prospective students in deciding to continue their studies to university, namely because of image or university name (brand image), facilities provided, offered curriculum, education cost, and strategic location factors.

In the midst of competition in the world of education, Politeknik Indonusa Surakarta presents as one of vocational colleges under the auspices of Indonesia Build Foundation. Politeknik Indonusa has been established since August 7, 2002 currently managing five Diploma III study programs namely D3 Management Informatics, D3 Mechanical Engineering Automotive, D3 Mass Communication, D3 Hospitality, and D3 Pharmacy. Polytechnic Indonusa work gradually doing college branding strategy for 14 years. One way to develop good brand image is by prioritizing the fulfillment of consumers' needs. Politeknik Indonusa Surakarta realizes that good image of a college will give positive value in consumers' eyes and also can give description about the quality of the college.

In the pre-purchase stage, Public Relations has significant role to form and maintain mutually beneficial relationship between the organization and its public. Public Relations in principle is the process of communication. Each individual has the ability as a publicist, especially for himself. Communication according to Wilbur Schram is derived from the Latin word "communis" which means common or together (common). Communication is also interpreted as a form of human interaction that affect each other. Communication launched by the PR or Public Relations is of mutual communication (Two Ways Communication). The reciprocal function of the PR includes two things. First, the PR practitioner's outsourced activities should endeavor to grow positive image of the community towards all actions and policies of the organization or its institutions. Second, he seeks to identify, identify the things that can lead to negative attitudes and images in society before any action or policy is exercised.

PR activities aim to establish and maintain mutually beneficial relationship between the organization and its publics such as the definition of Public Relations formulated by Scott M. Cutlip, Allen H. Center and Glen M. Broom (1995: 6): "Public relations is the management function that establishes and maintains mutually beneficial relationships between an organization and the public on whom is success or failure 
defends. From the above understanding Public Relations is a management function that is closely related to traffic arrangements, internal and external information circulation and provide information and explanations to the public, especially prospective students about the policies, programs, and actions of the company to be understood to gain support and public acceptance."

One of the audiences considered important by Public Relations is the consumer, in this case is the student. Students as one of the external stakeholders are assets that need to be maintained. According to Rosady Ruslan (2001: 278), consumers are important for reasons such as (1) consumers as interested parties and appraisers of the existence, performance, and workings of the company concerned; (2) the positive first impression is the main thing for the consumer or a positive start for the company's service; (3) the consumers will be happy and satisfied if they are given good treatment and feel appreciated and cared for (4) when the consumer is satisfied, it will be an effective promotion and will convey to the parties to the satisfaction of the services that have been given by the company concerned; and (5) challenges for Public Relations to provide excellent service and in addition it requires efficient work standards and at the same time effective in conducting positive publications.

Gita Aprinta in his article (2014: 1-7) explains that positive image is required by every company or organization, without exception a higher education institution in this case is private university. Private colleges are units of higher education providers whose management and regulations are conducted by the private sector. The law enacted on 13 July 2013 on the autonomy of state universities established throughout Indonesia gives special impact for the sustainability of private universities. Competition is not just limited to fellow private universities but also state universities. If the management of the organization and the acceptance of new students into the autonomy of each state universities are good, it is not impossible that state universities are competing to open new programs to attract new student candidates. Image can be seen from various factors, one of which is the interest of prospective students in choosing the Private Higher Education for the continuation of learning.

Happiness and satisfaction of consumers are indications of the fulfillment of consumers' expectations. Expectations by Snyder, Irving \& Anderson (in Snyder, 2000: 8) suggest positive motivated state based on the interactive relationship between the agency (the energy that leads to the goal) and the pathway. From this understanding, it can be explained that the expectations are formed due to the interaction of students with things that support education and planning offered by Public Relations.

In the expectation according to Snyder (2000: 9) there are components that support it, namely (1) goal where human behavior is oriented and has direction of purpose. Goal or aim is the goal of the stage of mental action that produces the cognitive component. The goal provides the end point of the individual mental behavior stage. (2) Pathway Thinking, the process to achieve the goal, then the individual must see himself as an individual who has the ability to develop a path to achieve goals. (3) Agency Thinking, the motivational component of hope theory is the agency, i.e the capacity to use a path to achieve the desired goal.

Based on the description above, the expectation met will cause satisfaction. Satisfaction is defined by Kotler (2002: 42) as "feeling of pleasure or disappointment of someone who emerges after comparing perceptions or impressions of the performance or outcome of a product and its expectations." Dipler in Kotler (2004: 10) states that consumer satisfaction is the level of consumer perception of product performance 
according to the expectations of a consumer. When product performance is much lower than consumer expectations, consumers are not satisfied. Conversely, if the performance fits even beyond the expectations, the buyer feels happy. It can be concluded that consumers will be satisfied if the results in accordance with the expected and otherwise consumers will not feel satisfied if not according to expectations and in the end do not consume or reuse of the product.

As an obvious example of the form of satisfaction is the customer of the form of health services in the hospital. According to research conducted by Dinita Yularsih (2014: 8-16) it is explained that the element of customer satisfaction from the form of health services he obtained during the stay is that because the doctor can respond quickly to the patient's information and immediately draw conclusions either in terms of diagnosing the patient or the accuracy of deciding medical action which should be applied to the patient after knowing the type of disease.

From various backgrounds that have been submitted above, this study aims to test "the influence of brand image quality to students' expectation and satisfaction of lecture at Politeknik Indonusa Surakarta." This research for college managers can be used as inputs in determining the imaging strategy and knowing how the influence of brand image to the students' expectation and satisfaction during the lecture at Politeknik Indonusa and the most dominant factors to fulfill the expectation and satisfaction of students during the lecture at Politeknik Indonusa.

\section{Methodology}

Objects and Subjects of Research

This study was conducted on third semester students of each study programs in Politeknik Indonusa Surakarta. The population in this study are all students of the third semester of Politeknik Indonusa, amounted to 292 students. The criteria of systematic sampling for respondents, namely correspondent is able to assess expectations and satisfaction during the lecture is the third semester students of each study programs in Politeknik Indonusa Surakarta.

Data Sources and Data Collection Techniques

Sources of data used in this study include primary data and secondary data, namely (1). Primary Data, is data obtained from the questionnaires given to the selected respondents. (2). Secondary Data, is data collected by other parties in the form of written documents. Sampling technique of systematic sampling with sample criteria i.e students who have studied at least 3 (three) semester because students with the criteria are considered to have been able to do evaluation to the campus where they study. Students of this semester still have memories of their expectations formed in the past then compared with the results they get during their lectures. According to Arikunto (2002: 112) if the population of more than 100 people then it is taken up to 5\% -10\% or maximum of $30 \%$ of the population. In this study, it can be determined the number of samples by $30 \%$ of the number of students in 2016 amounted to 292 students, so the number of research samples are 100 respondents. The way of calculating the magnitude of each samples from the third semester students of each Study Program is as follows:
a. D3 Informatic Management
$=\frac{107}{292} \times 100=37$
b. D3 Mass Communication
$=\frac{44}{292} \times 100=15$
c. D3 Hospitality
$=\frac{51}{107} \times 100=17$

Jurnal The Messenger, Vol. 10, No. 1, January 2018, pp. 93-103 
d. D3 Automotive $\quad=\frac{40}{292} \times 100=14$

e. D3 Pharmacy $=\frac{50}{292} \times 100=17$

\begin{tabular}{|c|c|c|c|}
\hline No & Study Program & Amount & Prosentase \\
\hline 1 & D3 Informatic Management & 37 & $37 \%$ \\
\hline 2 & D3 Mass Communication & 15 & $15 \%$ \\
\hline 3 & D3 Hospitality & 17 & $17 \%$ \\
\hline 4 & D3 Automotive & 14 & $14 \%$ \\
\hline 5 & D3 Pharmacy & 17 & $17 \%$ \\
\hline & Total & 100 & $100 \%$ \\
\hline
\end{tabular}

Table 1. Systematic Sampling of Respondents

Operational Definition of Variables and their Measurements

Independent Variable

The independent variable consists of brand image. The brand image is the total picture of the mind of the customer or the target customer towards the product or brand. The indicators include: a) Location, b) Quality of Education, c) Academic Services, d) Complaint Service.

Dependent variable

The dependent variable in this study is the expectation of students with indicators include: Facilities of infrastructure, tuition fees, the existence of lecturers, practitioners, work placements, and the assessment of the use (consumption) that affects student satisfaction (Y2) of lectures at Politeknik Indonusa.

All variables are measured by Likert scale that weighs from 1 to 5 , with alternative answers from Strongly Disagree (SD) score 1, Disagree (D) score 2, Neutral (N) score 3, Agree (A) score 4, and Strongly Agree (SA) score 5.

Research Test Instrument Quality

Validity and Reliability Test

The validity test is performed to indicate the extent to which a measuring device measures what is measured or in other words whether the measuring instrument is appropriate for measuring the object under study (Kuncoro, 2003: 41). Validity test is done using Realibity Scale with the help of SPSS 22. The research instrument is said to be valid if the significance value is less than 5\%. Reliability is an index that indicates the extent to which a measuring instrument can be trusted or reliable (Kuncoro, 2003: 43). If the measuring instrument is used twice to measure the same symptoms and the results obtained are consistent, then the measuring instrument can be said to be independent. The research instrument is said to be reliable if the Cronbach Alpha value is greater than 0.6 (Sekaran, 2006: 182).

Hypothesis Analysis and Testing Tool

To answer H1, a simple regression analysis tool is used with regression equation as follows:

Equation (1)

$\mathrm{Y}=\mathrm{a}+\mathrm{b} 1 \times 1+\mathrm{e}$

Note:

$\mathrm{Y}=$ Expectations

$\mathrm{A}=$ Constants

$\mathrm{B} \quad=$ Regression Coefficient

$\mathrm{x} 1=$ Brand image 
$\mathrm{e} \quad=$ Error

Hypothesis 1 will be accepted if the significance value is at a significance level of 5\% (sig. <0.05).

To answer H2, simple regression analysis tool is used with regression equation as follows:

Equation (2)

$\mathrm{Y}=\mathrm{a}+\mathrm{b} 1 \mathrm{z} 1+\mathrm{e}$

Note:

$\mathrm{Y}=$ Satisfaction

$\mathrm{a} \quad=$ Constants

$\mathrm{b} \quad=$ regression coefficient

$\mathrm{z} \quad=$ Satisfaction

e $\quad=$ error

Hypothesis 2 will be accepted if the significance value is at a significance level of $5 \%$ (sig. <0.05).

\section{Result and Discussion}

Response to Questionnaire, Response Results and Respondents' Characteristics

In the independent variable of brand image (X1) there are four indicators that explain that $44 \%$ agree if location is an indicator of the variables affecting brand image, $55 \%$ of respondents agree if the quality of education affects brand image, $38 \%$ of respondents agree academic service is indicator of the variables affecting brand image, $35 \%$ of respondents agree if complaint service is an indicator that affects the brand image. In the dependent variable of students' expectation (Y1) there are four indicators that explain that $44 \%$ agree the availability of good facilities and infrastructure as one of the supporting variable of expectation, 35\% agree that affordable tuition fee is one of the supporting expectation variable, $43 \%$ agree that practitioner lecturer is one of expectation variable, and 35\% declare neutral to job placement after graduation is one of variable that influences students' expectation. In the dependent variable of students' satisfaction (Y2), there are 4 indicators that explain 39\% agree the convenience of college location as an indicator that influence the satisfaction variable, $47 \%$ agree that the subjects given is an indicator influencing the satisfaction variable, 38\% agree that evaluation is an indicator that affects the satisfaction variable, $31 \%$ declare neutral to the use of education costs as an indicator that affects the satisfaction variable.

Test Instrument Quality Results

Validity Test

The validity test in this research is done by using Realibility Scale with the help of SPSS 22. The research instrument is said to be valid when In Coloumn Cronbach's Alpha if they deleted is smaller than 0.749 so that no items of questions need to be revised or deleted. Therefore, it can be concluded they have the good validity. The test results obtain that all question items are declared valid. Here are the results of validity testing for each variables.

1. Variable of Politeknik Image

Item-Total Statistics

\begin{tabular}{|l|r|r|}
\hline & Cronbach's Alpha if Item Deleted & \multicolumn{1}{|c|}{ Note } \\
\hline X.1.1 &, 708 & Valid \\
\hline
\end{tabular}




\begin{tabular}{|l|r|r|} 
X.1.2 &, 723 & Valid \\
X.1.3 &, 660 & Valid \\
X.1.4 &, 669 & Valid \\
\hline
\end{tabular}

Table 2. Test Results Validity on Polytechnics Brand Image

2. Students' Expectation Variable

Item-Total Statistics

\begin{tabular}{|l|r|r|}
\hline & Cronbach's Alpha if Item Deleted & \multicolumn{1}{|c|}{ Note } \\
\hline X.2.1 &, 650 & Valid \\
X.2.2 &, 533 & Valid \\
X.2.3 &, 375 & Valid \\
X.2.4 &, 650 & Valid \\
\hline
\end{tabular}

Table 3. Test Results Validity of Students' Expectations

3. Students' Satisfaction Variables

Item-Total Statistics

\begin{tabular}{|r|r|r|}
\hline & Cronbach's Alpha if Item Deleted & \multicolumn{1}{|c|}{ Note } \\
\hline Y.2.1 &, 691 & Valid \\
Y.2.2 &, 678 & Valid \\
Y.2.3 &, 686 & Valid \\
Y.2.4 &, 724 & Valid \\
\hline
\end{tabular}

Table 4. Test Results Validity of Students' Satisfaction

Reliability Test

Based on the calculation using computer program of SPSS 22, the result got is that the measuring tool used is reliable because Cronbach's Alpha has greater than 0.6 (Sekaran, 2000: 76). The results presented in the reliability test attachment are summarized in Table 5.

\begin{tabular}{|l|l|l|}
\hline Variabel & Alpha & Status \\
\hline Brand Image & 0,749 & Reliable \\
\hline Students' Expectations & 0,706 & Reliable \\
\hline Students' Satisfaction & 0,755 & Reliable \\
\hline
\end{tabular}

Table 5. Reliability Test Results

Discussion on Brand Image of Politeknik Indonusa

Good universities always prioritize the quality of accredited education, the strategic location, provide good academic services and complaints services that make it easier for students. In this research result of the brand image variable (X1), there are four indicators that explain that $44 \%$ of respondents agree if the location is an indicator of the variables affecting the brand image, $55 \%$ of respondents agree if the quality of education affects the brand image, $38 \%$ of respondents agree that academic service is an indicator of the variables that affects the brand image, and 35\% of respondents agree if complaint service is an indicator affecting brand image. 
According to Schiffman and Kanuk (in Pradityas, 2011: 41), respondents agree and strongly agree due to several things such as good quality related to the quality of products and services offered by producers and with respect to the competence of teachers in it and the ability of graduates as well as the ease of graduates to get a job. The second indicator that states agree is trustworthy or reliable. Respondents agree because they are trustworthy or relied on the opinions or agreements established by the public about a service consumed. The third indicator that states agree is price. Respondents agree because the price is related to the high, low or a lot of the least amount of expenses incurred by consumers or students to study in the future.

If the image of the company is undoubtedly on its credibility, then the purchaser is no longer through long decision making. In this condition, it can be said that the image of the college brand has been formed through 4 indicators namely the location of the college, the quality of education, academic services, and complaint services.

Discussion on Students' Expectation

Snyder, Irving, \& Anderson (Snyder, 2000) expresses that hope is a positive motivated state based on the interactive relationship between the agency (the energy that leads to the goal) and the pathway.

There are four explanatory indicators of students' expectation or Y1 variable. 44\% agree that the availability of good facilities and infrastructure is one of the supporting variable of expectation, 35\% agree that affordable tuition fee is one of the supporting variable expectation, $43 \%$ agree that the availability of practitioner lecturer is one of expectation variable, and $35 \%$ declare neutral on job placement after graduation is one of the variables that influence students' expectation.

Although in the research results it is noted that one of the four indicators declare neutral and three indicators states agree can show that the expectation variable has significant effect on the students' satisfaction. Factors that affect the perception and expectations of consumers when making a purchase of goods or services is the need and desire felt by the consumer at the time of making a purchase of goods or services, past experience when consuming goods or services and experience of friends who have consumed such goods or services and advertising. In this case the respondents after conducting the lecture variables considered to be in accordance with the expectation are good infrastructure, the affordable cost and the availability of practitioner lecturers. Variable of job placement after graduation is considered neutral because not yet known on job placement after completion of lecture and there is not information from alumni experience obtained by the respondents.

Discussion ob Students' Satisfaction

According to Zeithaml and Bitner (2000: 75) the definition of satisfaction is the response of consumers related to the fulfillment of needs. Satisfaction is an assessment of the characteristics or features of the product or service, or the product itself, which provides the level of consumer pleasure associated with the fulfillment of consumer consumption needs. Consumers' satisfaction can be created through quality, service and value. There are four indicators that explain consumers' satisfaction or Y2. 39\% agree that the convenience of college location is an indicator that affects the satisfaction variable, $47 \%$ agree that the suitability of the given course is an indicator that affects the satisfaction variable, $38 \%$ agree that the use of facilities and infrastructure is an indicator that affects the satisfaction variable, and $31 \%$ agree and neutral that evaluation of the cost of education is an indicator that influences the satisfaction variable. 
Based on the research results it appears that respondents, variables that are considered appropriate and meet their satisfaction, are the comfort of location, suitability of courses, and the use of facilities and infrastructure variables. The evaluation variable of educational cost usage has the same result between neutral and agree. This is because students are not satisfied since there is not transparency on the use of funds to students or guardians of students. The results of these four indicators can be used by universities as a measurement of student satisfaction level. Considering in a competitive environment, an indicator that can indicate consumer satisfaction is whether the consumer will re-buy and re-use the product in the future. In this case, a satisfied student will recommend a college to relatives, neighbors and other relatives to continue their education at the college.

Discussion on the Influence of Brand Image on Students' Expectations and Satisfaction

Brand image can be one factor that affects the expectation. The brand image is representation of the overall perception of the brand and is shaped from the past information and experience of the brand. Consumers who perceive positive image of a brand will be more likely to make purchase.

Based on the result of research, the influence of the brand image to the students' expectation is that $\mathrm{F}$ count $=82,076>$ from ftabel $(3,94)$ and $\mathrm{R}$ count $=0,675>\mathrm{R}(0.05)$ $(98)=0,49$ with prob. $F$ count (sig.) in the table above is 0.000 smaller than 0.05 significance level. Therefore, it can be concluded that the linear regression model estimated to be suitable to explain the effect of brand image (X1) has significant effect on the expectation (Y1). The influence is interpreted that the brand image is one of the factors that influence the expectations of students. A good brand image then will be more motivate positively on the brand image so that many students are motivated to study at Politeknik Indonusa. Students also have positive expectations based on the interactive relationship between themselves and the campus from interaction with the environment around the campus, academic services, complaints services and infrastructure facilities. The interaction pattern is expected to support the pathway of the students after graduated from the college.

Based on the results of data analysis, it is obtained that $t$ value is 9.060 and table is 3.393 with significance of 0.000 , with determined significance level 0,05 or $5 \%$. The output obtains coefficient of determination (R2) of 0.450 which implies that the influence of brand image variable to the expectation variable is $45 \%$ while the rest is influenced by other variables. Based on the analysis, it can be concluded that the influence of brand image has positive and significant effects on the students' expectation, because $\mathrm{t}$ value is bigger than $\mathrm{t}$ table value $(9,060>3,393)$ and its significant value is smaller than specified $(0,000<0,05)$.

This research also looks at the effect of brand image variable on students' satisfaction. Based on the result of research, the influence of the brand image to the students' satisfaction is found that $\mathrm{F}$ count $=113,993>$ from $\mathrm{f}$ table $(3,94)$ and $\mathrm{R}$ count $=$ $0,733>\mathrm{R}(0.05)(98)=0,49$ with prob. $\mathrm{F}$ arithmetic (sig.) in the table above is 0,000 smaller than 0.05 significance level. Therefore, it can be concluded that the linear regression model estimated to be suitable to explain the effect of brand image (X1) has significant effect on satisfaction (Y1).

These results indicate that students get satisfaction from the image of Higher Education. Satisfaction received by students can not be separated because of the positive image built by universities. For example, universities always prioritize the location of strategic campus, the quality of education with accredited study programs, 
improving education services in the form of infrastructure facilities, and the balance of tuition fees by means of infrastructure provided to students. If the image of the company is undoubtedly on its credibility, then the purchase is no longer through long decision making. In this condition, it can be said that students' satisfaction has been formed against the college.

Students' satisfaction is also seen from the pattern of learning. Students' goal as a consumer oriented to the world of work is achieved with supporting material from the world of industry and procurement of industry practices then students feel the benefits. Benefits obtained are able to support the pathway thinking of the students themselves so that after graduated students can view themselves as individuals who have the ability that can be applied in the world of industry. In the end the Agency Thinking is motivational components and expectations of students during the course that have been met to achieve the world of work.

\section{Conclusion}

Based on the results of the research and discussion that have been described in the previous chapter, it can be concluded as follows: the results of the influence of image variables (X1) on students' expectations (Y1) has positive regression coefficient (R2) of 0.450 which implies that the influence of brand image variables to the variable expectation is $45 \%$ while the rest is influenced by other variables. Based on the analysis, it can be concluded that the influence of brand image has positive and significant effect on the students' expectation, because $t$ value is bigger than t table value $(9,060>3,393)$ and its significant value is smaller than specified $(0,000<0,05)$.

The result of the research on the influence of image variable (X1) on student satisfaction (Y2) has positive regression coefficient (R2) of 0,538 which implies that the influence of brand image variable to the expectation variable is $53.8 \%$ while the rest is influenced by other variables. The influence of brand image has positive and significant effect on students' satisfaction, because $t$ value is bigger than $t$ table value $(10,677>$ $3,393)$ and its significant value is smaller than specified $(0,000<0,05)$.

Limitations in this research lies in the presence of other variables that have not been studied so that this study is less perfect, because this study only examines the image and expectation variables. There are still other variables that can affect students' satisfaction during college in Politeknik Indonusa Surakarta.

From the research result, the suggestion for Politeknik Indonusa Surakarta that they should always try to maintain or even improve the good image that already owned because it will increase the satisfaction of the students that will guarantee the continuity of Politeknik Indonusa. Suggestions for future researchers that they should be able to expand the research object that can reach more private universities in Surakarta region.

Through the development of methods in sampling, the results of further research can provide stronger generalization and expand the range of existing research, so that further research can be further developed, obtain better results and refine this research by using more variables that will be analyzed to provide higher value. Therefore, it can produce differences with the results of research on students' satisfaction in 2016.

\section{Acknowledgement}

Thank God, I pray to God Almighty who has bestowed His blessings and grace, so that I can finish the research entitled "The Influence of Brand Image to Students" 
Expectation and Satisfaction of Lecture at Politeknik Indonusa Surakarta." This research is a research with institutional grant funding so I would like to thank to:

1. Suci Purwandari as the Director of Politeknik Indonusa who has given us the widest opportunity to develop ourselves in the research activities.

2. Head of Research Unit, Institute of Research and Community Service and staffs who have provided many technical support, facilities, and administration to smoothen the research.

3. Students in the third semester of 5 study programs that have cooperated in filling out questionnaires and giving positive feedback for this research.

\section{References}

Aprinta, G. (2014). Strategi Cyber Public Relations dalam Pembentukan Citra Institusi Pendidikan Tinggi Swasta. Jurnal The Messenger, 6 (1), 1-7.

Arikunto, S. (2002). Prosedur Penelitian, Suatu Pendekatan Praktek. Jakarta: PT Rineka Cipta.

Cutlip, M.S., Center, A.H., Broom, G.M. (1995). Effective Public Relations, $7^{\text {th }}$ Edition. New Jersey: Prentice-Hall Inc.

Kotler, P. (2002). Edisi Millenium, Manajemen Pemasaran. Jakarta: PT Prenhalindo.

Kotler, P. (2004). Dasar - dasar Pemasaran. Jakarta: PT Gramedia.

Kuncoro, M. (2003). Metode Riset Untuk Bisnis \& Ekonomi: Bagaimana Meneliti \& Menulis Tesis. Jakarta: Erlangga.

Pradityas, K. (2011). Analisis Pengaruh Brand Image, Biaya Pendidikan, dan Fasilitas Pendidikan Terhadap Keputusan Mahasiswa Melanjutkan Studi Pada Program Diploma III Fakultas Ekonomi Universitas Diponegoro Semarang. Semarang: Universitas Diponegoro.

Sekaran, U. (2006). Metodologi Penelitian untuk Bisnis, Edisi 4, Buku 2. Jakarta: Salemba Empat.

Ruslan, R. (2001). Manajemen Humas dan Komunikasi. Jakarta: PT. Raja Grafindo Persada.

Snyder, C.R. (2000). Hypothesis: There is Hope. Dalam C. R. Snyder (Ed). Handbook of Hope: Theory, Measures, and Application. San Diego, CA: Academic Press.

Yularsih, D. (2014). Penerapan Komunikasi Terapeutik pada Proses Penyembuhan Pasien di Bangsal Keperawatan RSUD Kota Semarang. Jurnal The Messenger, 6 (2), 8-16.

Zeithaml, V.A., Bitner, M.J. (2003). Service Marketing. New York: McGraw Hill Inc, Int'1 Edition. 